\title{
Livelihood improvement through family poultry farming in Mymensingh district
}

\author{
M. S. Kabir ${ }^{1^{*}}$, M. Asaduzzaman ${ }^{1}$ and D. S. Dev ${ }^{2}$ \\ ${ }^{1}$ Department of Rural Sociology, ${ }^{2}$ Department of agricultural Extension Education, Bangladesh Agricultural University, \\ Mymensingh-2202, Bangladesh, *E-mail: mskabir786@gmail.com
}

\begin{abstract}
The present study was done to examine the employment and income generation of small farmers through family poultry. The objectives of the study were to identify socio economic features of family poultry, to examine the impact of family poultry on household improvement, to determine cost, return and profitability of family poultry, to identify the problems faced by family poultry farmer and for its improvement. The data were collected from 90 family poultry farms from Sadarupazila and Trishalupazila of Mymensingh district through face to face interview. The result of the study shows that, the average gross return, gross cost and net return of family poultry farms were Tk. 7314.84, Tk. 3698.90 and Tk. 3615.94 respectively. The Benefit cost ratio was 1.98 . Therefore, family poultry farm is highly profitable. The study also determined the impact of family poultry production on livelihood of poultry farmers. The income of $60 \%$ poultry farms has increased and for savings, it was $32 \%$. The physical assets (agricultural tools and furniture and equipment's) of poultry farms have improved by $57 \%$ and $27 \%$ respectively. Sanitation, drinking water facility and medicinal facility of poultry farmers were improved by $26 \%, 18 \%$ and $37 \%$ respectively. It is also found from the study that the livelihood of $38 \%$ poultry farmers was improved through family poultry production.
\end{abstract}

Keywords: Livelihood, Family poultry, Improvement

\section{Introduction}

The agriculture sector of Bangladesh contributes $17.02 \%$ of GDP of the economy (MOF, 2013). Livestock and poultry is an important part of agriculture in Bangladesh. For the development of the agrarian and largely subsistence economy of the country livestock and poultry sectors plays an important role. The rate of growth was 3.39 in the FY 2011-12 (MOF, 2012). To show those species of birds, which render an economic service and reproduce freely under proper care the term "poultry" was used. Poultry applies to chickens, turkeys, ducks, geese, swans, guinea, fowl, pings, peafowl, ostrich, pheasants, quails and other game birds (Banerjee, 1986). The situation of family poultry production was implies by the term family poultry. A number of technologies for increasing productivity and contributed substantially to generate income and reduce poverty, women empowerment and nutritional enhancement for building a poverty free and healthy society family poultry production system has introduced.

Around 89 percent of rural households in Bangladesh rear poultry through traditional production systems like "low input-low output". Their poultry production system is mainly associated with local chicken. Most birds are kept in small flocks under a scavenging system with feed generally available from household waste, homestead pickings, and crop residues. Local hen's productivity is low and losses due to incidence of diseases and predator animals, inefficient management systems, lack of supplementary feeding and inappropriate breeds (Saleque, 2001). A large number of poultry farms have been operating on commercial basis in and around the cities and are running under proper management. There are approximately 0.15 millions of poultry farmers in the country. More than 130 hatcheries are producing 3.4 millions of day-old-chicks per week. Thirty thousands of commercial broiler and layer farms supplying 0.26 million tons of poultry meat and 3500 million eggs per year (Rahman et al, 2007). The contribution of poultry industry is significant.

For the growth of agriculture and improvement of diet for the people in Bangladesh the poultry sub-sector is crucial. To fight against poverty not only for this group of people but also for the distressed women as poultry requires minimum land, short capital and skill it can be play as an important tool. In Bangladesh, the poultry sector is also an integral part of the farming system. Poultry meat is the fastest growing component of global meat production, consumption, and trade, with developing and transition economies playing a leading role in its expansion. In addition to providing opportunities to increase poultry exports, rising poultry production spurs growth in global import demand for feeds and other inputs and in 
investment opportunities in this sector. Meat is an excellent source of protein. Family poultry ensures the availability of poultry meat to the rural poor who suffer from malnutrition. Poultry meat is cheaper than beef, mutton, etc. It is generally accepted by all religion and casts. The poultry meat is also digestible with less fat comparatively with other animals. Family poultry production provides balance protein and income opportunities for the family.

For the improvement of the livelihood of resource poor farmers small scale family poultry plays an important role. By providing balance diet and helps in poverty alleviation in rural areas it is well accepted. The village women is generally kept family poultry. A remarkable change for the family was undertaken by family poultry. The livelihood pattern also improved by it. Balance nutrition among children of these families also maintained by family poultry. Earning from family poultry has a potential impact on total income of the poor farmer and helps to make better choice. Under this circumstances the study was done to identify the socio economic features of family poultry, to examine the impact of family poultry on household improvement, to identify the problems faced by family poultry farmer and for its improvement.

\section{Materials and Methods}

The present study was conducted under Mymensingh district in Trishal upazilla and Sadar upazilla. Among identified450 small farms (0.05-2.49 acres land holding) that have family poultry, 90 farm families were selected randomly in the study area. Primary data were collected from the sample respondent by direct interview method using a pre tested structured interview schedule during the months of January to March 2015. As analytical tool tabular technique was used to calculate profitability, average, percentage, total, etc., and for multiple regression analysis, Cobb-Douglas production function was used because in Cobb-Douglas production function, the regression coefficients directly shows production elasticities and as all the sum of the production elasticities indicate whether the production process as an increasing, constant, or decreasing returns to scale.

To assess the relationship between the profitability and resource use in the production process of family poultry Cobb-Douglas production function was used. Cobb-Douglas model was used to estimate the production function as

$$
\ln Y=\alpha+\beta_{1} \ln X_{1}+\beta_{2} \ln X_{2}+\beta_{3} \ln X_{3}+\beta_{4} \ln X_{4}+\beta_{5} \ln X_{5}+U_{i}
$$

Where,

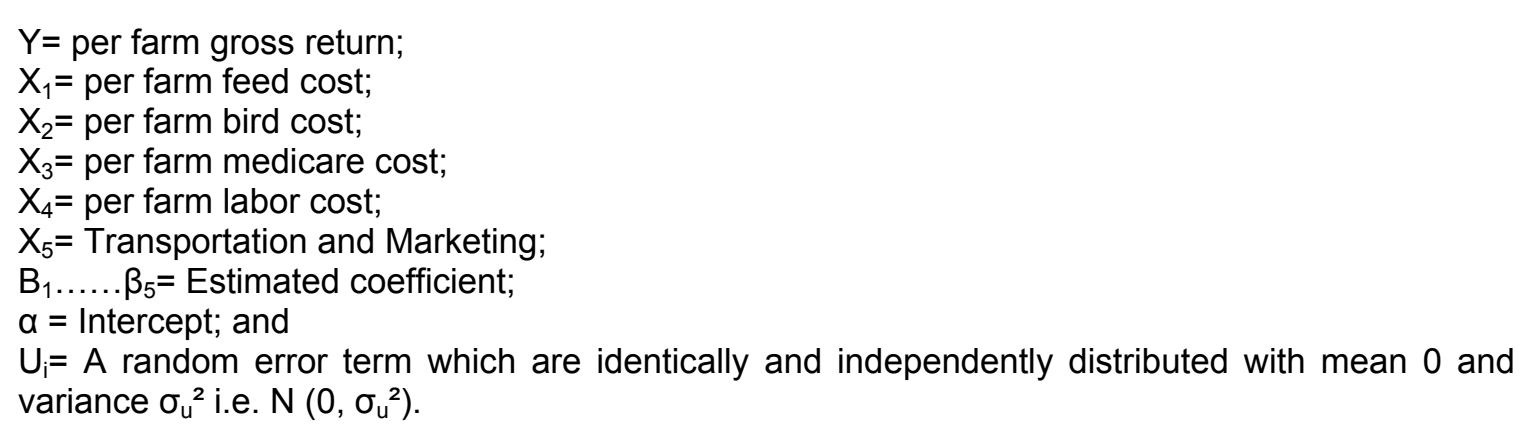

\section{Results and Discussion}

It is essential to know the socio-economic characteristics of the poultry keeper, to examine the impact of family poultry farming on the livelihood improvement. The daily life of farmers influenced by their socioeconomic characteristics. Some socio-economic characteristics such as occupational status, farm size, etc., are discussed in the following sections.

\section{Farm Size}

From the Table 1 it is evident that $53 \%$ poultry growers had their own land. Twenty percent give their land mortgage out and $27 \%$ percent farmers have rented in land. 
Table 1. Land information of the family poultry farmers

\begin{tabular}{lcc}
\hline Land type & Number & Percentage \\
\hline Own land & 48 & 53 \\
Rented/Mortgage in & 24 & 27 \\
Rented/Mortgage out & 18 & 20 \\
\hline Total & 90 & 100 \\
\hline
\end{tabular}

Source: Field survey, 2015.

\section{Occupational status of the family poultry farmers}

The main occupation of the respondents in the study area is agriculture $40 \%$ and business constituted $22 \%$, service constituted $16 \%$ and others constituted $22 \%$ (Table 2). Others occupation means rickshaw pulling, day labor etc. In case of subsidiary occupation, family poultry farming being chosen by $100 \%$ respondents that means all farmers were reported to be involved in family poultry farming.

Table 2. Occupational status of the family poultry farmers

\begin{tabular}{l|cc|c|c}
\hline \multirow{2}{*}{ Name of the occupation } & \multicolumn{2}{|c|}{ Main } & \multicolumn{2}{c}{ Subsidiary } \\
\cline { 2 - 5 } & Number & Percentage & Number & Percentage \\
\hline Business & 20 & 22 & & \\
Agriculture & 36 & 40 & 90 & 100 \\
Family poultry & 0 & 0 & & \\
Service & 14 & 16 & & 100 \\
Others & 20 & 22 & 90 & \\
\hline Total & 90 & 100 &
\end{tabular}

Source: Field survey, 2015.

\section{Cost, return and profitability analysis}

In the study to analyze their profitability the costs and returns of family poultry are estimated. The cost items include: housing, tools and equipment, birds purchasing cost, feed cost, labor cost, transportation and marketing cost and interest on operating capital. The resource of family poultry included returns from eggs and bird sales. Total cost, gross returns, net returns and benefit-cost ratio have been determined and discussed.

\section{Costs}

The cost items were classified into two broad categories, i.e. (i) Fixed costs and (ii) Variable costs. Family poultry production includes different types of costs under the following heads.

\section{Fixed Cost}

Housing cost: Some poultry house found within the living house and some were outside of living houses found in the study. By using old tins, iron sheets, woods, bamboos and plastic bags the outside poultry living houses are often made. The cost of housing was calculated by determine into account of the depreciation cost and repairing cost. Table 3 shows that the average cost of housing facilities was $8.11 \%$ of the total cost.

Tools and equipment cost: Various tools and equipment like cooking pots, water jar, egg cage, plastic bowls, clay pots and tin cans are used for feeding and drinking. By applying straight-line depreciation method the cost for tools and equipment was determined for one year. The annual depreciation cost was calculated as follows:

Depreciation $=($ Original value-salvage value $) /$ Life of the asset 
Table 3. Annual average costs of family poultry

\begin{tabular}{lc|c}
\hline Items of cost & Taka & Percentage of total cost \\
\hline Variable cost & & \\
Feed cost & 860 & 23.25 \\
Cost of birds & 350 & 9.46 \\
Medicare cost & 180 & 4.87 \\
Labor cost & 1500 & 40.56 \\
Transportation \& Marketing & 200 & 5.41 \\
Interest on operating capital & 164.25 & 4.44 \\
Sub total & 3254.25 & \\
Fixed cost & 300 & 8.11 \\
Depreciation on housing cost & 144.65 & 3.91 \\
Depreciation on poultry equipment & $\mathbf{4 4 4 . 6 5}$ & \\
\hline Sub total & $\mathbf{3 6 9 8 . 9 0}$ & $\mathbf{1 0 0}$ \\
Total cost &
\end{tabular}

Source: Field survey, 2015.

\section{Variable Cost}

Bird purchasing cost: The primary cost for the family poultry farmer is bird purchasing cost which varies from one family to another according to the numbers and size of poultry. Average price of parent stocks was Tk. 300-350 per hen and Tk. 350-400 per duck being found in the study area. The annual average purchasing cost of birds was $9.46 \%$ of total cost in the study area (Table 3 ).

Feed cost: The opportunity to scavenge is a way of allowing the chickens to correct any nutritional deficiency in the feeds offered as supplements. Family poultry usually have to find food for them. Feeding is mainly limited to insects and kitchen wastes, bran (mainly rice) and whole grains are sometimes used as well. In this study, the annual average feed cost per family was $23.25 \%$ of total gross cost (Table 3 ). Bran is given wet or dry in various containers or on bare ground.

Human labor cost: Most of the labor was given by female person. The cost of hired labor is very less for the family poultry. Usually women work one or two hours per day besides their household chores. Human labor cost was $40.56 \%$ of total gross cost being found in the study area (Table 3 ).

Medicare cost: Family poultry production involve some medicare cost which is another important cost item. Medicare cost included cost of vaccine, medicine and fees of vet. It is reported by the respondents that medicare cost is negligible. It is amounted Tk. 155 to 210per year. Total Medicare costs were calculated at current market prices. The annual average medicare cost was $4.87 \%$ of total cost (Table 3 ).

Transportation \& marketing cost: Transportation and marketing cost included expenses on transportation for purchasing chicks, parent stock, feed etc. and for selling chicken and eggs. Transportation and marketing cost per family per year stood at $5.41 \%$ of total cost (Table 3 ).

Return: The value of chicken and duck sell, egg, chicks and gift, etc. indicate the return items. The value of adult poultry was calculated on the basis of weight $(\mathrm{kg}$.) of live birds sold, multiplied by the average prices of that birds prevailing in the market. The value of per adult chicken is Tk. 280 to Tk. 300 and per duck is Tk. 355 to Tk. 390 found in the study area. The price of egg fluctuates with market price. Generally it varies from Tk. 28- Tk. 40 per hali. The average price of egg is Tk. 95 to 120 per dozen. Total return, total cost and net return for each family poultry farmer is presented in Table 4.

Gross return: By multiplying the numbers of poultry sold in a year with the average price of per poultry Gross return is calculated. The average value of Gross return was Tk. 7314.84 , which is shown in Table 4. 
Net return: By deducting all the costs from the gross returnnet return is obtained. The average net return is Tk. 3615.94which is shown in Table 4.

Benefit cost ratio: Return per taka invested is implied by the term Benefit Cost Ratio. It represents the financial feasibility of any farm. In the present study, the value of BCR was 1.98 . So, the family poultry farming is profitable and financially efficient.

Table 4. Gross return, gross margin, and net return of family poultry

\begin{tabular}{lc}
\hline Particular & Taka \\
\hline Chicken and egg & 3250 \\
Sold & 1905.43 \\
Consumed & 5155.43 \\
Total (1+2) & 2159.41 \\
Value of present stock & 7314.84 \\
Gross Return (3+4) & 3254.25 \\
Total Variable Cost (TVC) & 3698.90 \\
Total Cost (TC) & 4060.59 \\
Gross Margin (5-6) & 3615.94 \\
Net Return (5-7) & 1.98 \\
Benefit-cost ratio (5/7) & \\
\hline
\end{tabular}

Source: Field survey, 2015.

\section{Profitability Analysis}

Cobb-Douglas production function was employed to investigate the factors affecting production of family poultry through production function analysis because in the Cobb-Douglas production function, the regression coefficients directly represent production elasticities and as all the sum of the production elasticities indicate whether the production process as an increasing, constant, or decreasing returns to scale.

Table 5. Estimated values of coefficient and their related statistics for Cobb-Douglas production function

\begin{tabular}{lcc}
\hline Variables & Estimated coefficient & t-statistic \\
\hline Feed cost $\left(\mathrm{X}_{1}\right)$ & $0.46^{* *}$ & 7.12 \\
Bird cost $\left(\mathrm{X}_{2}\right)$ & $0.37^{* *}$ & 3.45 \\
Medicare cost $\left(\mathrm{X}_{3}\right)$ & 0.24 & 1.26 \\
Labor cost $\left(\mathrm{X}_{4}\right)$ & $0.8^{*}$ & 2.41 \\
Transportation and marketing cost $\left(\mathrm{X}_{5}\right)$ & 0.18 & 1.23 \\
Intercept & 2.26 & 4.87 \\
$\mathrm{R}^{2}$ & 0.88 & \\
F-value & 218.58 & \\
Returns to scale & 1.54 & \\
\hline
\end{tabular}

Notes: ${ }^{* *}$ Significant at 1 percent probability level, ${ }^{*}$ Significant at 5 percent probability level.

Source: Field survey authors estimation, 2015.

It appears from Table 5 that the estimated coefficients of the Cobb-Douglas model. It also appears from table that the regression coefficients of bird and feed for family poultry were positive and significant at 1 percent level of significant. Labor for family poultry was positive and significant at 5 per cent level of significance.

One percent increase in bird cost and feed cost keeping other factors constant would result in increase in the gross returns by 0.37 and 0.46 percent for family poultry farm, respectively indicated by the result of the analysis. The transportation and marketing cost have positive effect on production, but in the study area farmers usually have little transportation and marketing cost. Generally they used to go to the village 
market by walk. For that reason this important variable is insignificant. In the study area, generally poultry farmers did not purchase medicine for their poultry birds. If any disease occurred, they brought medicine from local dispensary for their poultry birds. The cost of medicine was very low in the study area. Therefore this important variable cost is insignificant.

The F-value of the equation is significant at 1 percent level of confidence implying that the variation in poultry farms depends mainly on the key explanatory variables included in the model. The overall performance of the Cobb-Douglas model for family poultry was satisfactory as indicated by the estimated $R^{2}$ and F-values. The value of the coefficient of determination $R^{2}$ was 0.88 , which indicates that the CobbDouglas model was good fitted by the independent variables.

The estimated regression coefficients of Cobb-Douglas production represent the coefficient of elasticities of production. The returns to scale are said to be constant if the sum of these of the regression coefficient is equal to unity, increasing if the sum of the regression is greater than unity and decreasing if the sum is less than unity. In the present study the returns to scale of poultry farm was computed by the sum of regression coefficients of poultry farm that were presented in the Table 5 . The sum of elasticities of conventional inputs stood at 1.54 for poultry farms. It was observed that the summation of elasticities of different inputs for poultry farms was positive and greater than one, implying that the production function exhibited increasing returns to scale.

\section{Impact analysis on livelihood improvement of family poultry farming}

The aim of this section is to present the impact of family poultry farming on livelihood improvement after family poultry rearing. The key objective of this section is to determine the changes in different types of livelihood assets, food intake, health, sanitation, etc.

\section{Livelihood}

The set of capabilities, assets, and activities that furnish the means for people to meet their basic needs and support their well-being is called livelihood. The building of livelihoods reflects and seeks to fulfill both material and experiential needs. Livelihoods are not simply a localized phenomenon, but connected by environmental, economic, political and cultural processes to wider national, regional and global arenas (Castro, 2002).

\section{Livelihood assets}

The members of a family combine their capabilities, skills and knowledge with the different resources at their disposal to create activities that will enable them to achieve the best possible livelihood for themselves and their family as a whole. Everything that goes towards creating that livelihood can be thought of as a livelihood asset. The livelihood framework identifies five core assets or capital upon which livelihoods are built. These assets can be divided into financial assets, physical assets, health and sanitation be developed depending on local circumstances these are all elements of livelihoods influence households directly or are potentially controlled by them.

\section{Financial assets}

Financial resources such as saving, income, bond, debenture, etc. include financial assets. In this study information about saving and income as major financial resources of the poultry farmers were identified. Table 6 reveals that, $32 \%$ of the poultry keeper responded that their saving increased after family poultry farming while $68 \%$ opined that no change in their household saving has taken place. Again $60 \%$ of the farmers felt that their family income got increased due to income earned from family poultry while the rest $40 \%$ respondents mentioned that no change in income took place.

\section{Physical assets}

The household goods, tools, equipment and physical infrastructure of the households refer as Physical assets. It is evident from Table 6 that $27 \%$ of the family poultry farmers responded that their stock of physical assets ( Furniture) increased due to income earned from farming while $73 \%$ was responded indicating no change in their household furniture. Again, $57 \%$ farmers said that their agricultural tools and equipments have increased from that profit while $43 \%$ responded no change. 
Changes in health and sanitation

The livelihood of the family largely influenced by Health and sanitation facilities. It indicates that $18 \%$ of the farmer opined in favor of improving their drinking water condition while $26 \%$ and $37 \%$ responded that their toilet condition and medicinal facility respectively has improved due to income earned from family poultry farming.

Table 6. Changes in financial assets, physical assets and health and sanitation conditions

\begin{tabular}{|c|c|c|c|c|}
\hline \multirow{3}{*}{ Particulars } & \multicolumn{4}{|c|}{ Degree of change } \\
\hline & \multicolumn{2}{|c|}{ Increased } & \multicolumn{2}{|c|}{ Unchanged } \\
\hline & Number & Percentage & Number & Percentage \\
\hline \multicolumn{5}{|c|}{ Financial Assets } \\
\hline Saving & 29 & 32 & 61 & 68 \\
\hline Income & 54 & 60 & 36 & 40 \\
\hline \multicolumn{5}{|c|}{ Physical Assets } \\
\hline Furniture & 24 & 27 & 66 & 73 \\
\hline Agricultural tools and equipments & 51 & 57 & 39 & 43 \\
\hline \multicolumn{5}{|c|}{ Health and sanitation } \\
\hline Drinking water & 16 & 18 & 74 & 82 \\
\hline Sanitation facility & 23 & 26 & 67 & 74 \\
\hline Medicinal facility & 33 & 37 & 57 & 63 \\
\hline
\end{tabular}

Source: Field Survey, 2015.

\section{Changes in Overall Socio-economic Conditions}

The results of the study reveals that $38 \%$ of the farmers responded that their socio-economic condition got improved due to family poultry while $62 \%$ responded no change in their overall socio-economic condition had taken place due to family poultry farming.

Table 7. Changes in overall socio- economic conditions of poultry keepers

\begin{tabular}{lcc}
\hline Types of changes & Number & Percentage \\
\hline Improved & 34 & 38 \\
Not improved & 56 & 62 \\
\hline
\end{tabular}

Source: Field survey, 2015.

\section{Impact analysis for Family poultry keepers}

To know the impact of family poultry on various facilities of family poultry households a table was prepared. The findings indicate that family poultry farming how can bring a significant change in any family. The Table 8 shows that the family poultry keepers have an opportunity to education, income generation, savings, daily protein intake, recreation facility etc. They also have a positive attitude to the investment activities. Women empowerment increased due to family poultry. They met up their daily necessities such as paying school fee for their children, buying food and medicine, purchasing household equipments etc. with the help of family poultry.

\section{Problems and some suggestions in family poultry farming}

The status of the family poultry farming is not satisfactory which is quite obscure and full of risk and uncertainty. It is suffering from various problems and does not have a scope to compete with the commercial poultry farm. Lack of adequate and authentic market information, no reliable statistics on supply-demand situation etc. make the household farming back behind. 
Table 8. Impact family poultry on the household

\begin{tabular}{c|lc|c}
\hline SL No. & Particular/facilities & Family poultry keeper & Percentage \\
\hline 1 & Daily protein intake & Increase \\
2 & Education level & High \\
3 & Women empowerment & Increase \\
4 & Nutritional value & Increase \\
5 & Disease attack & Decrease \\
6 & Family income & Increase \\
7 & Employment & Increase \\
8 & Savings & Increase \\
9 & Social security & Increase \\
10 & Self-dependency & Increase \\
11 & Recreation facilities & Increase \\
12 & Social status & Increase \\
13 & Investment attitude & Positive \\
\hline
\end{tabular}

Source: Field survey, 2015.

\section{Economic problems}

Lack of capital and credit institution: Capital is very much essential input for establishing any kind of enterprise or venture. Table 9 represent that 72 farmers mentioned this problem. Moreover, formal credit is mostly unavailable for this kind of work as maximum institution doesn't offer credit for specific this purpose, reported by 40 farmers. Therefore farmers borrowed money from land lord or mahazon or other person against high interest rate. These creates problems as most of the income of the farmers goes paying the high interest.

Higher price of feed: Higher feed price is one of the major problem in family poultry farming. Table 9 shows that 63 farmers reported this problem. Because of high price of feed, farmers are unwilling to buy good feed which lessens the production of good quality poultry. Generally they use their daily residual rice as food.

Price fluctuation of poultry: Profit is not sure as the price fluctuation is high in case of poultry farming. The major factors for poultry production are risk and uncertainty. Table 9 represents that 59 farmers reported this problem. Sometimes due to sudden attack of disease price rate of poultry become low. As the poultry producers are rural poor, this kind of uncertainty discourages them to invest in poultry farming.

\section{Social and natural problems}

Problem of thief: Table 9 shows that 43 poultry keepers reported this problem. Mainly adult poultry birds attracts the thieves. This kind of problem lessens the profit ratio.

Predatory animals: This is a very common problem in rural areas. Table 9shows that 66 farmers mention the problem of predator animals. Predators such as snakes, rats, dogs, cats, foxes, and birds of prey represent the main causes of predator losses, especially in young birds. Proper shelter should be constructed using locally available materials.

Outbreak of diseases: Outbreak of diseases is a serious problem in case of poultry farming. Din recent past, a number of diseases were observed in Bangladesh. In the selected area farmers faced very dangerous diseases such as, Gumboro, Ranikhet, Fowl pox, Fowl cholera, Bird flu, Heat stress, Pullorum etc. Specially in recent time bird flu create havoc for poultry farmers and causes a great deal of loss. Table 9 shows that 77 farmers reported this problem.

Environmental pollution: The ducks and chickens polluted the whole environment of the surrounding areas. It generates bad smell which leads to a quarrel with the owner families. It is a problem for the neighbor and they give serious objection to establish poultry farm in residential areas. Table 9 shows that 54 farmers faced this problem. 


\section{Marketing Problems}

Lower price of poultry meat and egg: Price of poultry egg and meat is low .Farmers complained that they were not getting reasonable price. As the farmers are rural poor they do not get the same price which prevails in the urban market. Table 9 shows that 26 farmers reported this problem.

Lack of competitive market: Family poultry farmer has not faced any competitive market situation. They face no competition in selling their products so they don't get their desired price. Sometimes they sell for very low prices to the villagers. They do not have any fixed buyer who can buy regularly at a real price. Table 9 shows that 39 farmers faced this problem.

\section{Technical Problems}

Lower quality of chick: Normally local breeds are produced in the rural poultry farms. These birds are exposed to natural selection from the environment for hardiness, running and flight skills, but not for egg production. Hens are thus poor layers, but good mothers. Local varieties of poultry are very sensitive to diseases and have a high mortality. If the birds are affected by diseases, they ultimately lose weight and sometimes died. Most of the farmers were facing the same problem Table 9 shows that 21 farmers told they suffer the growth problem because of lower quality of chick.

Lack of training facilities: Training is very essential for proper poultry production but according to farmers they have no proper training on poultry production. Farmers performance would be improved if they could be trained by livestock officials. About 24 farmers feel necessity of training (Table 9).

Housing problem: Most of the farmers did not know how to make proper house. For this reason, birds did not get good aeration and faced too many crises. Proper housing facilities could help to attain better production. It was revealed that 45 farmers felt that they had poor conception about poultry housing (Table 9).

Inadequate parent stock: Parent stock was not available in family poultry production. Genetic potential is the most important for parent stock. Local variety have not enough growth potentiality .This problem was faced by 14 farmers.

Table 9. Problems faced by the family poultry farmers

\begin{tabular}{lcc}
\hline Problems & Number of responding farmers $(\mathrm{N}=90)$ & Ranking \\
\hline Economic problems & & 2 \\
\hline High price of feed & 63 & 1 \\
Lack of capital & 72 & 3 \\
Price fluctuation of poultry & 40 & 4 \\
Lack of credit institution & & 2 \\
\hline Social and natural problems & 66 & 1 \\
\hline Predatory animals & 77 & 3 \\
Outbreak of diseases & 54 & 4 \\
Environmental pollution & 43 & 1 \\
Problem of theft & & 2 \\
\hline Marketing problem & 39 & 1 \\
\hline Lack of competitive market & 26 & 2 \\
Lower price of Egg & & 3 \\
\hline Technical problems & 45 & 4 \\
\hline Housing problem & 24 & \\
Lack of training facilities & 21 & \\
Lower quality of chick & 14 & \\
Inadequate parents stock & & \\
\hline
\end{tabular}

Source: Field survey, 2015. 


\section{Measures suggested by family poultry farmers}

The farmers put forward following suggestions to overcome these problems of family poultry rearing and to make family poultry farming more profitable:

- Feed cost should be minimized and feed should be available for the family poultry farm level at reasonable price opined by farm owners. They must be ensured stable and reasonable price of poultry and providing price incentives.

- To get rid of the problem of shortage of fund, short term loan for poultry farming should be made on easy terms and conditions by government and NGO's.

- Most of the respondents suggested that government should increase veterinary services by supplying necessary vaccine and medicine at lower price and by establishing new veterinary care centers.

- The respondents suggested that government and NGO's should take proper steps like increasing social awareness about family poultry and provide training of poultry rearing for efficient management.

- Most of the farmers suggested that there should be proper training facilities on family poultry production as it will increase their ability to do poultry farming work properly.

\section{Conclusion and Recommendation}

Bangladesh is a developing country. The economy of Bangladesh depends on agriculture to a great extent. In respect of nutrition, poultry meat and eggs are excellent sources of protein. Family poultry can create a great opportunity for the rural women and youth in income generation. Socio economic development can be achieved with the help of family poultry farming. There is a wide scope for development of family poultry farming in the country because rural poor women have enough time for rearing family poultry. It would be helpful for income generation, women empowerment, and nutritional improvement for the farm family.

The following recommendations are made based on this research for the improvement of existing production of family poultry.

- Feed standardization and price control measures should be stricter to make the feed available for the farmers.

- To control diseases regular vaccination program should be arranged.

- Local market with good transport and sell opportunities should be established.

- More research should be taken place to improve the quality of breed, feed, vaccine, to know the actual demand and supply condition and there by disseminate the information.

- Training should be given to the farmers in the areas of disease control, housing, equipment, feeding, genetic improvement and marketing. Local craftsmen could be trained to manufacture small equipment, such as feeders and drinkers

\section{References}

Banerjee, G.C. 1986. A Text Book of Animal Husbandry, Fifth edition, Oxford and IBH Publishing Co. Pvt. Ltd., New Delhi-110001.

Bangladesh Bureau of Statistics. 2010. Statistical Year Book of Bangladesh, Statistical Division, Ministry of Planning, Government of the People's Republic of Bangladesh, Dhaka, Bangladesh.

Castro, P.A. 2002. Sustainable Livelihoods Analysis: An introduction. Syracuse University: New York

Ministry of Finance, 2013. Bangladesh Economic Review, Finance Division, Government of the People's Republic of Bangladesh.

Rahman, M.A.R, Abdullah-Al-Amin, M. and Howlider, M.M, Ahmmed, M.M. 2007. "An Article on Disposal of Layer Droppings Reared in Case and Impact on Environment Pollution", J. Bangladesh Agri. Uni., 7(2): 281-290, 2009.

Saleque, M.A. and Islam, M.M. 2001. "Small-Scale Broiler Rearing As an Income Generating for Hard-Core Women in Rural Bangladesh", Bangladesh J. Res., Vol.9(1\&2). Bangladesh Livestock Research Institute. Saver, Dhaka-1341. 